\title{
IMPLIKASI PUTUSAN MAHKAMAH KONSTITUSI NOMOR 92/PUU-X/2012 DAN ALTERNATIF MODEL HUBUNGAN KELEMBAGAAN TERKAIT PEMBENTUKAN UNDANG-UNDANG*
}

\author{
Enny Nurbaningsih ${ }^{* *}$
}

Bagian Hukum Tata Negara, Fakultas Hukum Universitas Gadjah Mada, Yogyakarta
Jalan Sosio Yustisia Nomor 1, Bulaksumur, Sleman, D.I. Yogyakarta 55281

\begin{abstract}
Presidential System Government as the result of 1945 Constitution Amandments has not been accomplised yet since its implementation reminds anomaly. President (executive) in presidential system has decision authority to produce acts with House of Representatives (DPR), without involving People Council (DPD) as one of parlement chambers. To restore DPD legislation role, Constitutional Court Decision No. 91/ PUU-X/2012 states that DPD has equal position with DPR and President in acts establishment. It implicates that DPD should be involved since the legislation planning, but still does not have authority to make decision even for bills concerned with its authority. This Constitutional Court brings about the trilateral relationship model in legislation process without any institutional construction towards interchambers relation between DPD and DPR. It will result in Judicial Review despite the involvement of DPD in phase 1 and 2 Process, since this involvement does not bind DPR and President.
\end{abstract}

Keywords: tripartite, law establishment.

\section{Intisari}

Sistem pemerintahan presidensial hasil revisi UUD 1945 belum tuntas karena implementasinya masih memunculkan keganjilan, Presiden (eksekutif) dalam sistem presidensial ikut mengambil keputusan untuk menghasilkan undang-undang bersama DPR, tanpa pelibatan peran DPD sebagai salah satu kamar di parlemen. Untuk memulihkan peran legislasi DPD bidang tertentu, Putusan Mahkamah Konstitusi No. 92/PUU-X/2012 menyatakan bahwa DPD berkedudukan setara dengan DPR dan Presiden dalam proses pembentukan undang-undang. Implikasi dari putusan ini DPD dilibatkan mulai dari proses perencanaan legislasi, tetapi tetap tidak dapat mengambil keputusan sekalipun untuk RUU terkait dengan kewenangannya. Putusan MK melahirkan model hubungan trilateral proses legislasi tanpa ada konstruksi secara kelembagaan terhadap hubungan interkameral antara DPR dan DPD. Hal ini akan akan berdampak pada pengujian undang-undang, walaupun DPD telah dilibatkan dalam proses tahap 1 dan tahap 2, karena pelibatan ini tidak mengikat DPR dan Presiden.

Kata Kunci: tripartit, pembentukan undang-undang.

\section{Pokok Muatan}

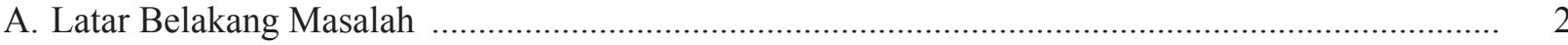

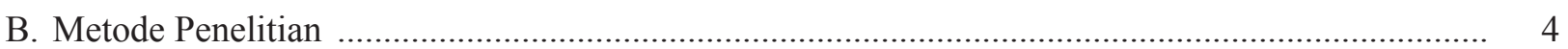

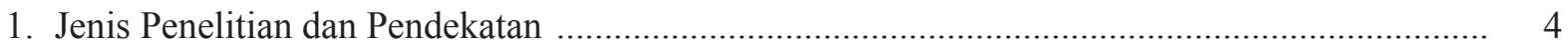

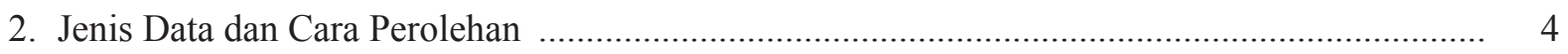

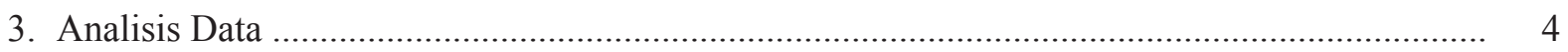

C. Hasil Penelitian dan Pembahasan ....................................................................................... 5

1. Implikasi Pembentukan Undang-Undang Pasca-Putusan Mahkamah Konstitusi ....................... 5

2. Model Hubungan Kelembagaan Pembentuk Undang-Undang ................................................ 9

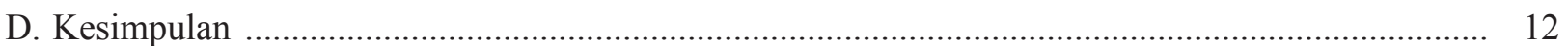

Hibah penelitian dari Pusat Penelitian dan Pengabdian Masyarakat Fakultas Hukum UGM, 2014.

Alamat korespondensi: enny@ugm.ac.id 


\section{A. Latar Belakang Masalah}

Hasil revisi UUD 1945 telah mengubah sistem dan struktur parlemen Indonesia dari yang semula menganut unicameral menjadi bicameral (soft) yang ditandai dengan adanya kelembagaan Dewan Perwakilan Rakyat (DPR) yang mewakili aspirasi partai politik, dan Dewan Perwakilan Daerah (DPD) yang mewakili kepentingan daerah. ${ }^{1}$ Harapannya agar aspirasi konstituen lewat partai politik dan yang berkembang di daerah memiliki pintu penyaluran yang komprehensif di parlemen. Dalam kenyataannya aspirasi daerah sulit disalurkan oleh DPD karena Pasal 22D UUD1945 terkait dengan kewenangan DPD dirumuskan tidak menggunakan diksi yang mengandung norma obligatori, sehingga oleh pembentuk UndangUndang (DPR dan Presiden), DPD ditafsirkan sebagai "lembaga bantu", bukan organ utama negara (main state organ) dengan kejelasan fungsinya. Munculnya tafsir ini karena sejak awal revisi UUD ada ketidakjelasan sistem pemerintahan yang dianut, semangat pengubah UUD memegang teguh sistem presidensial, tetapi muatan revisi mengarah pada unsur parlementer karena keterlibatan Presiden (eksekutif) dan DPR dalam pengambilan keputusan untuk undang-undang (UU), sedangkan DPD yang mewakili suara rakyat di daerah tidak memiliki hak untuk itu.

Persoalan ini bermuara pada rumusan UUD 1945 dengan frase DPD "dapat mengajukan"2 rancangan undang-undang (RUU) bidang tertentu kepada $\mathrm{DPR}^{3}$ dan dikaitkan dengan frase "ikut membahas", yangmenyebabkanDPDdisfungsional. ${ }^{4}$ Kedua frase ini diintepretasikan sebagai tugas lembaga bantu. Penjabaran ini diperkuat oleh UU No. 27 Tahun 2009 tentang MPR, DPR, DPD dan DPRD (UU MD3). Akibat dari ketentuan ini DPD tidak mendapatkan kesempatan terlibat dalam proses penting yang menentukan hajat hidup orang banyak, khususnya hajat daerah dalam pembentukan UU. Selain UU-MD3 yang menutup peluang DPD melaksanakan fungsi legislasi, UU No. 12 Tahun 2011 tentang Pembentukan Peraturan Perundangundangan (UU P3) juga ikut memposisikan DPD sebagai sub-ordinat DPR dengan kedudukan setara alat-alat kelengkapan DPR. ${ }^{5}$ Ketentuan pasal-pasal dalam kedua UU ini yang kemudian diujikan ke Mahkamah Konstitusi (MK).

MK mengabulkan permohonan pengujian dengan memberikan tafsir atas Pasal 22D UUD 1945 agar tidak lagi menimbulkan kesalahan tafsir atas ketentuan yang dianggap selama ini tidak obligatori, menjadi sebagai berikut: ${ }^{6}$

Pilihan sistem parlemen ini tidak terkait dengan bentuk negara dan sistem pemerintahan, tetapi karena kebutuhan untuk membangun pemerintahan yang lebih demokratik konstitusional. Lihat Miriam Budiardjo, 2006, Dasar-Dasar Ilmu Politik, Gramedia Pustaka Utama, Jakarta, hlm. 180, dan Bagir Manan, 2004, Teori dan Politik Konstitusi, Fakultas Hukum UII Press, Yogyakarta, hlm. 34.

Pasal 22D ayat (1) Undang-Undang Dasar Negara Republik Indonesia Tahun 1945.

RUU bidang terkait otonomi daerah, hubungan pusat dan daerah, pembentukan dan pemekaran serta penggabungan daerah, pengelolaan sumber daya alam dan sumber daya ekonomi lainnya, serta yang berkaitan dengan perimbangan keuangan pusat dan daerah.

Pasal 22D ayat (2) Undang-Undang Dasar Negara Republik Indonesia Tahun 1945, bahwa DPD ikut membahas rancangan undang-undang yang berkaitan dengan otonomi daerah; hubungan pusat dan daerah; pembentukan, pemekaran, dan penggabungan daerah; pengelolaan sumber daya alam, sumber daya ekonomi lainnya, serta perimbangan keuangan pusat dan daerah; serta memberikan pertimbangan kepada Dewan Perwakilan Rakyat atas rancangan undang-undang anggaran pendapatan dan belanja negara dan rancangan undang-undang yang berkaitan dengan pajak, pendidikan, dan agama. Aktualisasinya kata "dapat" dan "ikut" tidak membuat DPD mempunyai kekuasaan legislatif yang efektif untuk menjadi salah satu institusi dalam proses legislasi. Lihat Saldi Isra, 2009, Pergeseran Fungsi Legislasi dalam Sistem Pemerintahan Indonesia Setelah Perubahan Undang-Undang Dasar 1945, Disertasi, Program Pascasarjana Fakultas Hukum Universitas Gadjah Mada, Yogyakarta, hlm. 403. Lihat juga Bivitri Susanti, "Penguatan Kewenangan DPD dan Pasal-Pasal Lain yang Terkait di Bidang Legislasi, Anggaran dan Pengawasan”, Makalah, disampaikan dalam Pertemuan Ahli Hukum Tata Negara, Universitas 45 Makassar, Makassar, 30 Juni 2007.

Dalam praktik bicameral, keberadaan DPD dengan kewenangan yang amat terbatas tetapi legitimasi tinggi (represents the odd combination of limited powers and high legitimacy), sangat tidak lazim.

Putusan Mahkamah Konstitusi Nomor 92/PUU-X/2012 perihal Pengujian Undang-Undang Nomor 27 Tahun 2009 tentang Majelis Permusyawaratan Rakyat, Dewan Perwakilan Rakyat, Dewan Perwakilan Daerah, dan Dewan Perwakilan Rakyat Daerah dan UndangUndang Nomor 12 Tahun 2011 tentang Pembentukan Peraturan Perundang-Undangan terhadap Undang-Undang Dasar Negara Republik Indonesia Tahun 1945, 27 Maret 2013. 


\begin{tabular}{|c|c|c|}
\hline Ketentuan UUD & Tafsir MK & Implikasi ke UU \\
\hline $\begin{array}{lr}\begin{array}{l}\text { Dewan } \\
\text { Daerah Perwakilan } \\
\text { dapat } \\
\text { mengajukan kepada }\end{array} \\
\text { Dewan Perwakilan } \\
\text { Rakyat rancangan } \\
\text { undang-undang }[\ldots . .] \\
(\text { Pasal 22D ayat (1)). }\end{array}$ & $\begin{array}{l}\text { Ketentuan Pasal 22D ayat (1) } \\
\text { merupakan pilihan subjektif DPD "untuk } \\
\text { mengajukan" atau "tidak mengajukan" } \\
\text { RUU yang berkaitan dengan fungsi DPD. } \\
\text { Kata "dapat" bermakna juga sebagai } \\
\text { sebuah hak dan/atau kewenangan, } \\
\text { sehingga analog dengan hak dan/atau } \\
\text { kewenangan konstitusional Presiden } \\
\text { dalam Pasal } 5 \text { ayat (1) UUD 1945. }\end{array}$ & $\begin{array}{l}\text { Seluruh produk UU terkait dengan } \\
\text { kedudukan dan kewenangan } \\
\text { DPD dalam pelaksanaan fungsi } \\
\text { legislasi harus disesuaikan dengan } \\
\text { makna "hak" DPD mengajukan } \\
\text { RUU sebagaimana Pasal } 5 \text { ayat } \\
\text { (1) UUD 1945. }\end{array}$ \\
\hline $\begin{array}{lr}\text { Dewan } & \text { Perwakilan } \\
\text { Daerah } & \text { ikut } \\
\text { membahas } & \text { rancangan } \\
\text { undang-undang }[\ldots . .] \\
(\text { Pasal 22D ayat }(2)) .\end{array}$ & $\begin{array}{l}\text { DPD sebagai lembaga negara mempunyai } \\
\text { hak dan/atau kewenangan yang sama } \\
\text { dengan DPR dan Presiden dalam } \\
\text { membahas RUU yang berkaitan dengan } \\
\text { fungsinya. }\end{array}$ & $\begin{array}{l}\text { Seluruh muatan UU terkait dengan } \\
\text { kedudukan dan kewenangan } \\
\text { DPD harus menempatkan DPD } \\
\text { setara dengan DPR dan Presiden } \\
\text { dalam proses pembentukan UU } \\
\text { mulai dari penyiapan Prolegnas, } \\
\text { pengusulan, dan pembahasan UU, } \\
\text { kecuali mengambil persetujuan. }\end{array}$ \\
\hline
\end{tabular}

Pemaknaan oleh MK ini merupakan bentuk perubahan konstitusi tanpa mengubah teks, namun implementasinya yang berubah. Hakim tidak melakukan perubahan secara tekstual pada original intent suatu konstitusi, melainkan hanya menafsirkan pasal-pasal (textual meaning) dari konstitusi supaya tidak dipahami keliru oleh pengambil kebijakan, khususnya DPR dan Presiden dalam merumuskan UU. Penafsiran ini merupakan wilayah otoritatif MK dalam kedudukannya sebagai "the guardian and the interpreter of the constitution". Jika diklasifikasikan Putusan MK tersebut mencakup:

1. menyatakan tidak berlaku dan tidak memiliki kekuatan mengikat terhadap beberapa pasal dalam UU MD3 dan UU P3 yang diujikan.

2. menyatakan berlaku dengan syarat (conditional constitutional), beberapa pasal dari UU MD3 dan UU P3.

Sebagai implikasi Putusan MK ini, menuntut adanya proses yang berbeda, karena akan muncul posisi 3 (tiga) lembaga negara dalam pembentukan UU a triparty system in the law making process".

Terkait dengan kekuasaan legislatif, Presiden bersama-sama DPR memegang legislative power dalam negara, karena setiap RUU harus disetujui bersama oleh DPR dan Presiden. Presiden sebagai pemegang kekuasaan eksekutif dalam sistem presidensial ikut mengambil keputusan untuk menghasilkan undang-undang bersama DPR. Sementara itu DPD sekalipun dimaknai oleh MK mempunyai "hak" untuk kewenangan yang sudah ditentukan dalam Pasal 22D UUD 1945, tetapi hak tersebut tidak mudah direalisasikan jika konstruksi hubungan interkameral dalam sistem parlemen belum dibangun. Jika disain tripartit dimunculkan tanpa kejelasan konsep legislasi justru akan memunculkan persepsi publik bahwa membentuk UU di Indonesia menjadi lebih sulit daripada mengubah konstitusi yang merupakan staatgrundgesetz. ${ }^{7}$

Persoalannya adalah sejak saat Putusan MK diucapkan, lahir beberapa UU yang terkait dengan

Maria Farida Indrati Soeprapto, 2002, Kedudukan dan Materi Muatan Peraturan Pemerintah Pengganti Undang-Undang, Peraturan Pemerintah, dan Keputusan Presiden dalam Penyelenggaraan Pemerintahan Negara di Republik Indonesia, Disertasi, Program Pascasarjana Universitas Indonesia, Jakarta, hlm. 80. 
kewenangan legislasi tertentu DPD, tetapi tidak melibatkan DPD. Selama ini pemahaman umum atas kewenangan DPD disempitkan hanya terkait dengan muatan UU otonomi daerah alias UU Pemerintahan Daerah (Pemda). Padahal jika dicermati kewenangan DPD di bidang otonomi daerah sangat luas berkaitan dengan seluruh urusan yang telah diserahkan ke daerah. ${ }^{8}$ Urusan tersebut berkaitan dengan berbagai sektor. Artinya bukan hanya muatan UU Pemda yang harus melibatkan DPD tetapi semua UU dengan muatan terkait urusan pilihan dan urusan wajib. Namun, pada kenyataannya terdapat beberapa rancangan UU yang diajukan pasca Putusan MK tanpa melibatkan DPD, misal UU Desa. Dalam hal proses pembentukan UU inilah perlu dikaji lebih jauh apakah mengalami cacat prosedural yang berpeluang untuk diuji ke MK karena tidak sejalan dengan putusan MK akibat ketidakjelasan hubungan interkameral. Berdasarkan hal tersebut, fokus penelitian meliputi: Pertama, implikasi Putusan Mahkamah Konstitusi Nomor 92/PUU-X/2012 terhadap kewenangan pembentukan UU; dan Kedua, alternatif model hubungan kelembagaan seperti apa dalam proses pembentukan UU ke depan pasca Putusan MK.

\section{B. Metode Penelitian}

\section{Jenis Penelitian dan Pendekatan}

Penelitian ini merupakan penelitian hukum (legal research) ${ }^{9}$ yang menggunakan beberapa pendekatan untuk dapat menjawab permasalahan yang diteliti, yaitu: (1) pendekatan undangundang (statute approach), pendekatan konseptual (conceptual approach), dan pendekatan historis (historical approach). ${ }^{10}$ Pendekatan perundangundangan digunakan untuk dapat mengkaji secara mendalam berbagai peraturan yang mengatur tentang proses pembentukan peraturan perundangundangan. Pendekatan konseptual digunakan untuk dapat memahami sistem parlemen Indonesia dalam kaitan dengan interkameral pembentukan
UU. Pendekatan historis digunakan dalam rangka memahami perkembangan proses legislasi di Indonesia, khususnya sejak awal reformasi yang menempatkan DPD dengan fungsi legislasi terbatas. Dari ketiga pendekatan tersebut dapat dipahami hal yang melatarbelakangi perumusan ketentuan kewenangan DPD, yang dalam implementasinya menjadi disfungsional.

\section{Jenis Data dan Cara Perolehan}

Data yang diperlukan dalam penelitian ini yang utama adalah data sekunder yang diperoleh dengan melakukan studi dokumen terhadap:

a. Bahan hukum primer, yaitu bahanbahan hukum yang mengikat berupa UUD hingga peraturan perundangundangan di bawahnya dan dokumen hukum lainnya yang berkaitan dengan pembentukan undang-undang;

b. Bahan hukum sekunder yang memberikan penjelasan mengenai bahan hukum primer, yaitu risalah sidang pembahasan kekuasaan legislatif, bahan-bahan hasil penelitian yang terkait dengan tema utama penelitian ini dan hasil-hasil pembahasan dalam berbagai forum;

c. Bahan hukum tersier atau bahanbahan hukum penunjang seperti kamus hukum, ensiklopedia, dan bahan lain di luar bidang hukum seperti politik, sosial, dan sebagainya yang dipergunakan untuk melengkapi data penelitian.

Untuk mendukung perolehan data sekunder, diperlukan pula pandangan atau pendapat ahli hukum perundang-undangan melalui wawancara dengan daftar pertanyaan yang disusun secara terbuka, sehingga memungkinkan ahli menyampaikan masukan secara lebih leluasa.

\section{Analisis Data}

Dalam penelitian hukum normatif ini

\footnotetext{
Lihat Pasal 12 Undang-Undang Nomor 23 Tahun 2014 tentang Pemerintahan Daerah (Lembaran Negara Republik Indonesia Tahun 2014 Nomor 244, Tambahan Lembaran Negara Republik Indonesia Nomor 5587).

F. Sugeng Istanto, 2007, Penelitian Hukum, Ganda, Yogyakarta, hlm. 29.

Peter Mahmud Marzuki, 2005, Penelitian Hukum, Kencana Jakarta, hlm. 93-94.
} 
pengolahan data dilakukan secara kualitatif. Bahan-bahan hukum tertulis yang telah terkumpul disistimatisasi sesuai dengan permasalahan yang diteliti. Selanjutnya bahan hukum tersebut dikaji dan diuraikan sesuai dengan permasalahannya dengan menggunakan landasan teori yang relevan. Untuk menjawab permasalahan kedua, terhadap bahan hukum yang telah disistimatisasi ini dilakukan penilaian sehingga dapat menjawab dengan tepat proses legislasi tripartit dalam kaitan dengan sistem parlemen menurut UUD 1945.

\section{Hasil Penelitian dan Pembahasan \\ 1. Implikasi Pembentukan Undang-Undang Pasca-Putusan MK}

Sekalipun MPR ketika merevisi UUD 1945 telah bersepakat bulat untuk memperkukuh sistem pemerintahan presidensial yang stabil dan demokratis sesuai dengan pilihan politik pendiri negara, namun format ketatanegaraan Indonesia yang dihasilkan dalam revisi UUD 1945 belum mencerminkan sistem presidensial ${ }^{11}$ yang diharapkan karena unsurunsur parlementerisme masih melekat di dalamnya. Sangat jelas hal tersebut terumuskan dalam pelaksanaan fungsi legislasi. DPR memiliki kekuasaan membentuk UU (Pasal 20 ayat (1) UUD 1945), tetapi prosesnya tidak dapat dilakukan sendirian, harus melibatkan Presiden sebagai pemegang kekuasaan eksekutif. Proses pelibatan ini dimulai dari perencanaan legislasi hingga pengambilan keputusan. Tanpa ada keputusan kedua lembaga negara ini, suatu RUU tidak dapat menjadi UU. Mekanisme persetujuan bersama kedua kekuasaan ini mencerminkan bekerjanya unsur parlementerisme. Model pembentukan UU ini tidak berbeda dengan ketika masa Orde Baru (Orba). Pembedanya hanya pada perumusan norma fungsi legislasi DPR yang lebih diperkuat dengan memindahkan esensi Pasal 5 ayat (1) UUD 1945 asli ke dalam revisi Pasal 20 ayat (1) UUD 1945. Dari hasil revisi tersebut pemegang kekuasaan legislatif tidak mengenal pola pemisahan kekuasaan karena tetap dipegang oleh DPR dan Presiden.

Sementara itu DPD sebagai lembaga negara, bagian dari kamar di parlemen, yang dihasilkan dari revisi ketiga UUD 1945 (2001) tidak diatur dengan kewenangan yang proporsional. Padahal DPD dipilih secara langsung untuk mewakili daerah dengan mekanisme sistem distrik berwakil banyak. Pada konteks ini ada ketidaksinkronan untuk mengatur fungsi legislasi DPD karena materi muatannya sudah terlanjur dihabiskan pada saat revisi pertama UUD sebagai ranah kewenangan DPR (1999). DPD tidak mendapatkan porsi untuk menjalankan kekuasaan legislatif sekalipun untuk bidang tertentu. MPR tidak dapat menata ulang dan mensinkronkan hasil revisi UUD 1945 dengan mengatur pola pendistribusian kekuasaan antara lembaga-lembaga negara secara proporsional sesuai dengan niat awal memperkukuh sistem presidensial. Jika pada masa pemerintahan Orba, MPR dapat memproduksi produk legislasi (Ketetapan MPR) sebagai komplemen dari kekurangan UUD, maka dengan mendasarkan pada ketentuan revisi Pasal 3 UUD 1945, MPR tidak dapat lagi menerbitkan ketentuan untuk menyempurnakan UUD.

Dalam kondisi ketidaksempurnaan UUD yang telah direvisi dalam empat tahapan (1999-2002), diterbitkan UU MD3. UU ini merupakan "payung hukum" yang mengatur susunan dan kedudukan lembaga parlemen. Muatan UU MD3 (UU No. 27 Tahun 2009) semestinya dapat memodifikasi ketentuan yang terkait dengan kewenangan DPD dalam menjalankan fungsi legislasi bidang tertentu, tetapi pada kenyataannya muatan UU hanya sekedar mengambil alih isi UUD. Cara pengaturan ini tidak sejalan dengan kehendak awal proses pembentukan UU MD3 sebagaimana terbaca dari isi penjelasan umum:

Dalam rangka penguatan fungsi legislasi

\footnotetext{
11 Arend Lijphart, 1995, Sistem Pemerintahan Parlementer dan Presidensial, Raja Grafindo Persada, Jakarta, hlm. 35 - 50. Lihat juga Jimly Asshiddiqie, 2006, Pengantar Ilmu Hukum Tata Negara, Sekretariat Jenderal Mahkamah Konstitusi Republik Indonesia, Jakarta, hlm. 60. Lihat juga Valina Singka Subekti, 2008, Menyusun Konstitusi Transisi: Pergulatan Kepentingan dan Pemikiran dalam Proses Perubahan UUD 1945, Raja Grafindo Persada, Jakarta, hlm. 4.
} 
DPR sebagai suatu pelaksanaan amandemen UUD NRI 1945, perlu pula diatur lebih lanjut mengenai penguatan peran DPR dalam proses perancangan, pembentukan, dan sekaligus pembahasan rancangan undang-undang. Hal tersebut dimaksudkan untuk menjawab kritik bahwa DPR kurang maksimal dalam menjalankan fungsi legislasi. Artinya adalah bahwa di satu sisi kinerja DPR yang berkaitan dengan legislasi diusahakan seoptimal mungkin, tetapi di sisi lain secara individual juga dituntut tanggung jawab untuk menghasilkan produk legislasi yang benar-benar berkualitas serta benarbenar berorientasi pada kebutuhan rakyat dan bangsa.

Perumusan UU ini menunjukkan otoritatif DPR karena dalam merumuskan fungsi legislasi DPD terkesan hati-hati, tidak jauh-jauh dari bunyi UUD bahwa:

Berkaitan dengan pelaksanaan fungsi legislasi, kedudukan DPD perlu ditempatkan secara tepat dalam proses pembahasan rancangan undang-undang yang berkaitan dengan otonomi daerah, hubungan pusat dan daerah, pembentukan, pemekaran, dan penggabungan daerah, pengelolaan sumber daya alam dan sumber daya ekonomi lainnya, serta perimbangan keuangan pusat dan daerah, sebagaimana diamanatkan dalam Pasal 22D ayat (2) Undang-Undang Dasar Negara Republik Indonesia Tahun 1945. Kedudukan DPD dalam proses pembahasan rancangan undang-undang tersebut sampai pada "pembahasan tingkat pertama" dan tidak turut serta dalam proses pengambilan keputusan.

Sama sekali tidak ada perubahan pengaturan yang memudahkan implementasi DPD dalam menjalankan fungsi legislasi bidang tertentu karena kedudukan DPD dalam proses pembahasan tingkat pertama hanya disetarakan dengan alat kelengkapan DPR, padahal DPD adalah lembaga negara yang setara dengan DPR dan Presiden. DPR tampak enggan berbagi kekuasaan dengan membuat rumusan norma yang dapat dikatakan sebagai bentuk modifikasi implementasi legislasi tanpa bertentangan dengan UUD. Fakta ini berbanding terbalik dengan keinginan DPR untuk menjamin keterwakilan rakyat dan daerah dalam melaksanakan tugas dan wewenang lembaga, serta mengembangkan mekanisme checks and balances antara lembaga legislatif dan eksekutif. ${ }^{12}$ Checks and balances antara DPR dan DPD hampir tidak ada. Sementara itu beban legislasi yang direncanakan DPR dan Presiden sebagaimana tertuang dalam Program Legislasi Nasional (Prolegnas) sangat tinggi, sementara itu capaiannya sangat rendah.

Tabel 1. Realisasi Prolegnas 2009 - 2014

\begin{tabular}{clll}
\hline Prolegnas & $\begin{array}{c}\text { Peren- } \\
\text { canaan }\end{array}$ & Realisasi & $\begin{array}{c}\text { Daftar } \\
\text { Kumulatif } \\
\text { Terbuka }\end{array}$ \\
\hline Prolegnas 2010 & 73 RUU & $8 \mathrm{RUU}$ & $7 \mathrm{RUU}$ \\
\hline Prolegnas 2011 & $91 \mathrm{RUU}$ & $19 \mathrm{RUU}$ & $5 \mathrm{RUU}$ \\
\hline Prolegnas 2012 & $69 \mathrm{RUU}$ & $10 \mathrm{RUU}$ & $20 \mathrm{RUU}$ \\
\hline Prolegnas 2013 & $75 \mathrm{RUU}$ & $11 \mathrm{RUU}$ & $11 \mathrm{RUU}$ \\
\hline Prolegnas 2014 & $69 \mathrm{RUU}$ & $21 \mathrm{RUU}$ & $11 \mathrm{RUU}$ \\
\hline
\end{tabular}

Perencanaan RUU pada hakikatnya adalah manajemen peraturan perundang-undangan yang disusun secara terencana, terpadu dan sistimatis. ${ }^{13}$ Seyogyanya tidak ada lagi usulan RUU yang dapat masuk Prolegnas kecuali yang termasuk kategori RUU Daftar Kumulatif Terbuka (DKT), yang ditentukan batasannya adalah: ${ }^{14}$

1. pengesahan perjanjian internasional tertentu;

2. $\quad$ akibat putusan Mahkamah Konstitusi;

3. Anggaran Pendapatan dan Belanja Negara;

4. pembentukan, pemekaran, dan penggabungan daerah Provinsi dan/ atau Kabupaten/Kota; dan

5. $\quad$ penetapan/pencabutan Peraturan

12 Maruarar Siahaan, "Checks And Balances dan Judicial Review dalam Legislasi di Indonesia”, http://www.jimlyschool.com/read/analisis/333/ checks-and-balances-dan-judicial-review-dalam-legislasi-di-indonesia/, diakses 27 Mei 2014. Lihat juga Jimly Asshiddiqie, Implikasi Perubahan UUD 1945 terhadap Pembangunan Hukum Nasional, Sekretariat Jenderal Mahkamah Konstitusi Republik Indonesia, Jakarta, hlm. 7.

13 Pasal 1 angka 9 Undang-Undang No. 12 Tahun 2011 tentang Pembentukan Peraturan Perundang-undangan. Lihat Machmud Aziz, "Peran Dewan Perwakilan Daerah dalam Pembentukan Undang-Undang”, Jurnal Legislasi Indonesia, Vol. 2, No. 3, September 2005.

14 Pasal 23 ayat (1) UU No. 12 Tahun 2011 Undang-Undang No. 12 Tahun 2011 tentang Pembentukan Peraturan Perundang-undangan (Lembaran Negara Republik Indonesia Tahun 2011 Nomor 82, Tambahan Lembaran Negara Republik Indonesia Nomor 5234). 
Pemerintah Pengganti UndangUndang.

Selain karena kategori DKT, masih ada kategori lain yaitu "dalam keadaan tertentu," DPR dan Presiden dapat mengajukan RUU di luar Prolegnas karena: ${ }^{15}$

1. untuk mengatasi keadaan luar biasa, keadaan konflik, atau bencana alam; dan

2. keadaan tertentu lainnya yang memastikan adanya urgensi nasional atas suatu Rancangan UndangUndang yang dapat disetujui bersama oleh alat kelengkapan DPR yang khusus menangani bidang legislasi dan menteri yang menyelenggarakan urusan pemerintahan di bidang hukum.

Dalam kenyataan RUU DKT meningkat fluktuatif per tahun, bahkan ada 2 (dua) RUU yang tidak termasuk dalam kategori tersebut tetapi muncul dalam longlist Prolegnas yaitu RUU tentang Perubahan Atas Undang-Undang Nomor 27 Tahun 2007 tentang Pengelolaan Wilayah Pesisir dan Pulau-Pulau Kecil dan RUU Perkebunan.

Sebagian RUU Prolegnas tersebut berkaitan dengan bidang-bidang tertentu yang merupakan arena kewenangan legislasi DPD. DPD tidak mungkin masuk dalam wilayah strategis penentuan arah politik Indonesia lima tahun ke depan, karena rencana Prolegnas dari DPD pada saat pembahasan Prolegnas 2010 - 2014, diperlakukan sebagai masukan kepada Badan Legislasi DPR, seperti masukan dari fraksi-fraksi DPR. Dengan ketidaksetaraan kedudukan DPR dan DPD ini maka usulan RUU tersebut tidak mengemuka hasilnya atau dapat saja didaku sebagai usulan DPR. Artinya checks and balances yang diinginkan oleh DPR seperti yang tersurat dalam penjelasan umum UU MD3, tidak berwujud nyata. Oleh karena itu
DPD lebih banyak beraktivitas melakukan kajian/ penelitian. Dalam kondisi ketidakmampuan menjalankan fungsi legislasi bidang tertentu tersebut, sementara energi legislasi yang tersedia sangat besar, maka DPD menyalurkannya secara konstitusional dengan mengajukan pengujian UU MD3.

Awalnya DPD berupaya bermanuver untuk mengusulkan UU tersendiri terkait dengan kedudukannya sebagai lembaga negara dengan mendasarkan pada istilah dalam teknis perancangan bahwa "diatur dengan" memungkinkan diajukan UU tersendiri sedangkan "diatur dalam" muatan perintahnya dapat diintegrasikan dengan UU yang lain. ${ }^{16}$ Pasal 19 ayat (2) UUD 1945: "Susunan Dewan Perwakilan Rakyat diatur dengan undangundang". Pasal 22C ayat (4) UUD 1945: "Susunan dan kedudukan Dewan Perwakilan Daerah diatur dengan undang-undang". Bertolak pada rumusan tersebut DPD menginginkan UU tersendiri. Manuver ini terganjal karena bola ada di dalam kekuasaan DPR, jika DPR tidak mengusulkan RUU tersendiri tersebut maka sampai kapanpun usulan tersebut tidak akan jadi UU walau secara teknis dimungkinkan.

Upaya lain yang secara paralel terus didorong DPD adalah mengajak berbagai elemen masyarakat merevisi kembali UUD 1945. Upaya ini terganjal Pasal 37 UUD 1945 karena DPD belum dapat menarik minat anggota MPR dari unsur DPR sesuai ketentuan Pasal 37 ayat (1) bahwa "Usul perubahan pasal-pasal UndangUndang Dasar dapat diagendakan dalam sidang Majelis Permusyawaratan Rakyat apabila diajukan oleh sekurang-kurangnya 1/3 dari jumlah anggota Majelis Permusyawaratan Rakyat".

Cara DPD menempuh menguji UU MD3

15 Pasal 23 ayat (2) Undang-Undang No. 12 Tahun 2011 tentang Pembentukan Peraturan Perundang-undangan (Lembaran Negara Republik Indonesia Tahun 2011 Nomor 82, Tambahan Lembaran Negara Republik Indonesia Nomor 5234).

16 Putusan MK Nomor 010/PUU-IV/2006 menyatakan Pasal 53 Undang-undang (UU) Nomor UU No. 30 Tahun 2002 tentang Komisi Pemberantasan Tindak Pidana Korupsi (UU KPK) yang berbunyi "Dengan Undang-Undang ini dibentuk Pengadilan Tindak Pidana Korupsi yang bertugas dan berwenang memeriksa dan memutus tindak pidana korupsi yang penuntutannya diajukan oleh Komisi Pemberantasan Korupsi", bertentangan dengan pasal 24A ayat (5) UUD 1945 yang berbunyi "Susunan, kedudukan, keanggotaan dan hukum acara Mahkamah Agung serta badan peradilan dibawahnya diatur dengan undang-undang”. MK berpendapat dari segi teknik perundang-undangan, frasa "diatur dengan undang-undang" berarti harus diatur dengan undang-undang tersendiri. 
sekaligus UU P3 merupakan langkah konstitusional yang patut diapresiasi, karena ini adalah bentuk checks and balances yang menggunakan tangan kekuasaan lembaga yudikatif. Putusan MK Nomor 92/PUU-X/2012 memberikan kepastian hukum terhadap penafsiran Pasal 22D ayat (1) dan (2) khususnya pada frasa "dapat mengajukan" dan "ikut membahas". Penafsiran MK ini sejalan dengan pendapat Laica Marzuki ${ }^{17}$ yang menegaskan bahwa kata "dapat" merupakan constitutional choice atau pilihan konstitusi yang diberikan kepada DPD. Artinya, apabila DPD menempuh pilihan mengajukan RUU kepada DPR maka pilihan yang ditempuh mengandung sifat imperatif. Tidak dapat dimodifikasi, tidak dapat direduksi, dibatasi, disimpangi, apalagi dinegasi oleh DPR dan Pemerintah. Dalam kata "dapat", terkandung hak dan kewenangan konstitusional DPD sebagai lembaga negara. Manakala DPD tidak menggunakan pilihannya, maka hal dimaksud merupakan rechtsverwerking (melepaskan hak). DPD sendiri yang menentukan pilihan konstitusional yang bakal diambil, bukan pihak lain. Oleh karena itu, idealnya kewenangan DPD meliputi: ${ }^{18}$

a. pengajukan RUU sesuai dengan bidang tugasnya (Pasal 22D ayat (1) UUD1945);

b. RUU yang diajukan DPD tidak berubah menjadi usul RUU DPR; dan

c. DPD dapat mengajukan RUU di luar Prolegnas.

Berlakunya Putusan MK ini menimbulkan keharusan pembenahan konsep dan mekanisme pembentukan undang-undang untuk mengatur kembali kewenangan DPD yang sebelumnya disejajarkan dengan fraksi, komisi atau gabungan komisi di internal DPR, berubah menjadi setara dengan kewenangan DPR dan Presiden dalam pembentukan undang-undang.

UU MD3 lama sudah tidak berlaku/dicabut dengan UU No. 17 Tahun 2014 (UU MD3 baru). UU baru ini seharusnya mengakomodasi Putusan MK Nomor 92/PUU-X/2012. Namun, UU MD3 baru ini tidak dimaksudkan untuk mengakomodasi Putusan MK, yang lebih utama dibentuk untuk mengatur secepatnya susunan dan kedudukan DPR dalam rangka mengantisipasi hasil pemilihan presiden langsung (2014). ${ }^{19}$ Mekanisme persetujuan DPR atas UU MD3 baru, terkesan terburu-buru tujuannya adalah untuk membuat ketentuan yang tidak memungkinkan partai pemenang Pemilu secara otomotis dapat menjadi pimpinan DPR, seperti sebelumnya. Proses politik ini berjalan sangat cepat, seluruh posisi pimpinan pada alat kelengkapan dewan pun dikonsepkan dengan rumusan yang tidak memungkinkan ruang bagi partai pemenang Pemilu beserta koalisinya dapat mengambil kursi pimpinan. Pertimbangan cermat kelompok oposisi dilakukan dengan mengkalkulasi jumlah kursi yang dapat dikuasai koalisi partai pemenang Pemilu (Koalisi Indonesia Hebat/KIH). Tanpa ada kursi pimpinan yang dikuasai partai pemenang Pemilu maka akan mudah bagi partai koalisi opisisi (KMP) untuk mengatur strategi pengambilan keputusan di DPR. Bacaan atas situasi politik ini sangat gamblang. Akibat konsentrasi DPR pada pengaturan struktur kepemimpinan DPR, menyebabkan bagian penting yang harusnya diatur dalam UU MD3 baru, khusus terkait dengan fungsionalisasi DPD pasca Putusan MK, menjadi kurang diperhatikan.

Hal ini menjadi pemicu DPD untuk mengajukan kembali permohonan judicial review atas UU MD3 baru. ${ }^{20}$ DPR sangat disibukkan dengan proses judicial review ini karena harus menyiapkan

Laica Marzuki, “Keberadaan DPD dan Kaitannya dalam Pembentukan Undang Undang”, Jurnal Legislasi Indonesia, Vol. 2, No. 3, September 2005.

18 Lihat Putusan MK Nomor 92/PUU-X/2012 perihal Pengujian Undang-Undang Nomor 27 Tahun 2009 tentang Majelis Permusyawaratan Rakyat, Dewan Perwakilan Rakyat, Dewan Perwakilan Daerah, dan Dewan Perwakilan Rakyat Daerah dan Undang-Undang Nomor 12 Tahun 2011 tentang Pembentukan Peraturan Perundang-Undangan terhadap Undang-Undang Dasar Negara Republik Indonesia Tahun 1945, 27 Maret 2013, hlm. 169

19 Tiga fraksi, PDIP, Hanura dan PKB yang masuk dalam Koalisi Indonesia Hebat (KIH) melakukan walk out karena tidak setuju dengan rumusan ketentuan yang dianggap mengebiri partai pemenang Pemilu.

20 DPD RI, "UU MD3 Dianggap Merugikan DPD RI Ajukan Permohonan Pengujian ke Mahkamah Konstitusi”, http://www.dpd.go.id/artikeluu-md3-dianggap-merugikan-dpd-ri-ajukan-permohonan-pengujian-ke-mahkamah-kontitusi, diakses 5 September 2014. UU MD3 dianggap inkonstitusional formil dan materiil. Inkontitusional formil diantaranya karena: (1) melanggar tata cara dalam melaksanakan perintah pendelegasian pembentukan UU, seharusnya dibentuk UU MPR, UU DPR, dan UU DPD; dan (2) proses pembentukan UU MD3 melanggar ketentuan Pasal 22D ayat (1) dan ayat (2) UUD 1945. DPD tidak diikutsertakan dalam proses pembentukan UU MD3. 
jawaban keterangan DPR atas ketentuan yang direview tersebut. Putusan MK yang bersifat final dan mengikat seharusnya langsung mengikat para pihak pada saat putusan tersebut dibacakan dalam sidang terbuka untuk umum. DPR tidak mempertimbangkan aspek hukum ini karena pasca putusan MK beberapa UU disahkan tanpa pelibatan DPD, misalnya UU Desa. UU ini sangat erat kaitan dengan DPD. Bahkan yang terakhir ketika DPR hendak merevisi sebagian UU MD3 baru dalam rangka mengakomodasi kepentingan partai pemenang pemilu yang tidak diakomodasi dalam struktur kepemimpinan alat kelengkapan DPR (AKD), DPD juga tidak diikutsertakan. Alasan untuk mempercepat proses digunakan DPR walaupun UU MD3 baru sudah memasukkan pengaturan pelibatan DPD. ${ }^{21}$

Upaya mengfungsionalisasikan fungsi DPD tidak cukup hanya dengan mengubah UU MD3 tetapi sekaligus mengubah UU P3 karena keduanya merupakan paket UU yang mengatur implementasi fungsi legislasi. Jika diinginkan dari awal DPD berdaya dalam proses legislasi bidang tertentu seharusnya pembentukan UU MD3 baru dapat dilakukan bersamaan dengan UU P3. Keduanya sama-sama masuk kategori RUU DKT, karena ada Putusan MK. Proses ini tidak dilakukan sehingga secara faktual ada ketidaksinkronan antara UU MD3 baru, tetapi UU P3 masih tetap yang lama.

\section{Model Hubungan Kelembagaan Pembentuk Undang-Undang}

Setelah berakhir masa keanggotaan DPR periode 2009 - 2014, berakhir pula masa berlaku Prolegnas 2010 - 2014. Tidak ada ketentuan yang mengatur hal ini tetapi menjadi konvensi yang hidup di kalangan DPR. Termasuk sebagai konvensi adalah DPR tidak mengenal carry over atas residu RUU yang tidak berhasil menjadi UU karena semuanya akan kembali pada titik nol tergantung pada kesepakatan politik yang berkembang pada saat pembahasan Prolegnas baru.

Selama belum ada perubahan proses pembentukan UU, maka mekanismenya sebagaian masih mengikuti UU P3 lama. Mekanismenya, diawali dengan perencanaan RUU Prolegnas yang disusun secara terencana, terpadu, dan sistematis. ${ }^{22}$ Prolegnas memuat rencana usulan UU untuk jangka menengah (5 tahun) dan tahunan. ${ }^{23}$ Semula kewenangan menyusun Prolegnas hanya pada DPR dan Presiden, tanpa melibatkan DPD. Ketentuan tersebut dinyatakan MK konstitusional bersyarat dengan memberikan DPD kewenangan yang sama dengan kewenangan DPR dan Presiden. Peran DPD dalam penyusunan Prolegnas tidak dapat disamakan dengan peran alat kelengkapan DPR lagi karena bertentangan dengan ketentuan dalam Pasal 22D ayat (1) UUD 1945..$^{24}$

Pasca Putusan MK Nomor 92/PUU-X/2012, penyusunan Prolegnas mengharuskan keterlibatan DPD dalam setiap tahapan, mulai dari pengajuan, pembahasan, dan penetapan Prolegnas. Dengan demikian terdapat 3 lembaga (tripartit) yang membutuhkan desain atau konsep baru dalam penyusunan Prolegnas. Sebagai akibat pertikaian politik antara kelompok KMP dan KIH, menyebabkan proses pembahasan Prolegnas belum dapat dimulai. DPD melalui alat kelengkapannya yaitu Panitia Perancang Undang-Undang, karena tidak terkait langsung dengan pertikaian tersebut sudah mulai menyusun konsep Prolegnas 20152019, bahkan mengundang rapat Menteri Hukum dan HAM. Sebelumnya hal ini tidak pernah dilakukan karena yang mengundang pembahasan Prolegnas hanya Badan Legislasi (Baleg) DPR.

Ke depan sudah jelas akan ada tiga usulan Prolegnas, yaitu usulan yang datang dari DPR, DPD dan Pemerintah. Artinya, model tripartit perlu didesain secara jelas karena pengalaman yang ada selama ini menunjukkan bahwa usulan RUU dalam Prolegnas dari DPR dan Pemerintah

21 Pasal 170 Undang-Undang Nomor 17 Tahun 2014 tentang Majelis Permusyawaratan Rakyat, Dewan Perwakilan Rakyat, Dewan Perwakilan Daerah, Dan Dewan Perwakilan Rakyat Daerah (Lembaran Negara Republik Indonesia Tahun 2014 Nomor 182, Lembaran Negara Republik Indonesia Nomor 5568).

22 Lihat Pasal 1 angka 9 Undang-Undang Nomor 12 Tahun 2011 tentang Pembentukan Peraturan Perundang-undangan (Lembaran Negara Republik Indonesia Tahun 2011 Nomor 82, Tambahan Lembaran Negara Republik Indonesia Nomor 5234).

23 Ahmad Yani, 2011, Pembentukan Undang-Undang dan Perda, Rajawali Pers, Jakarta, hlm. 31.

24 Lihat Putusan MK Nomor 92/PUU-X/2012 erwakilan Daerah, dan Dewan Perwakilan Rakyat Daerah dan Undang-Undang Nomor 12 Tahun 2011 tentang Pembentukan Peraturan Perundang-Undangan terhadap Undang-Undang Dasar Negara Republik Indonesia Tahun 1945, 27 Maret 2013, hlm. 167. 
hampir tidak pernah tuntas menjadi UU, bahkan ada RUU yang tidak pernah terbahaskan hingga masa keanggotaan DPR berakhir. ${ }^{25}$ Apalagi jika ada tambahan usulan RUU dari DPD. Dalam konteks ini perlu ada kesepakatan yang baik agar Prolegnas tidak hanya menjadi daftar keinginan (wishlist) sehingga jumlah RUU besar tetapi kemampuan untuk menyelesaikannya kecil/minim.

Parameter yang digunakan untuk mengusulkan RUU sebaiknya tetap mengacu pada Pasal 18 UU P3:

a. perintah Undang-Undang Dasar Negara Republik Indonesia Tahun 1945 ;

b. perintah Ketetapan Majelis Permusyawaratan Rakyat; ${ }^{26}$

c. perintah Undang-Undang lainnya;

d. sistem perencanaan pembangunan nasional;

e. rencana pembangunan jangka panjang nasional;

f. rencana pembangunan jangka menengah;

g. rencana kerja pemerintah, rencana strategis DPR (jika usulan DPR, dan rencana strategis DPD (jika usulan DPD ; dan

h. aspirasi dan kebutuhan hukum masyarakat.

Belajar dari pengalaman yang ada akibat ketidakberhasilan DPR dan Pemerintah menyelesaikan RUU yang sudah disepakti dalam Prolegnas, pemerintah telah membuat rambu-rambu yang memperketat keinginan kementerian/lembaga $(\mathrm{K} / \mathrm{L})$ mengusulkan RUU. Pengetatan ini sebagai bentuk pengejawantahan perintah Pasal 18 UU P3 bahwa setiap usulan RUU diarahkan paralel dengan Rencana Pembangunan Jangka Menengah (RPJM). Hasil penyiapan penyusunan Prolegnas jangka menengah merupakan arah kerangka regulasi untuk 5 tahunan. ${ }^{27}$ Dengan cara ini akan dapat terkurangi daftar RUU yang tidak perlu atau tidak seharusnya menjadi muatan UU. ${ }^{28}$ Rambu-rambu ini dimonitor oleh Kementerian Hukum dan Hak Asasi Manusia (Kemenkumham) sebagai koordinator untuk memastikan bekerjanya kerangka regulasi ini. ${ }^{29}$ Menteri dari $\mathrm{K} / \mathrm{L}$ terkait yang dilibatkan dalam proses ini adalah:

1. Menteri Dalam Negeri;

2. Menteri/Kepala Badan Perencanaan Pembangunan Nasional;

3. Menteri Sekretaris Kabinet; dan

4. Menteri Keuangan.

Bekerjanya kerangka regulasi ini akan menjadi salah satu cara mengurangi sektoralisme yang selama ini selalu menghinggapi cara kerja K/L, karena Presiden Joko Widodo sedari awal menggarisbawahi, setiap K/L hanya menjalankan visi dan misi Presiden, dalam rangka mewujudkan Nawacita (9 agenda prioritas). RUU yang diusulkan harus benar-benar merupakan jalan keluar terbaik memecahkan masalah yang menjadi hambatan mewujudkan Nawacita.

Kerangka regulasi hanya digunakan oleh Pemerintah untuk menentukan arah politik hukum ke depan, tidak bagi DPR dan DPD. Ukuran pengusulan RUU oleh DPR dan DPD tidak dijabarkan secara konkrit, karena DPR dan DPD belum mempunyai rencana strategis. Bagi DPD usulan RUU bisa mendasarkan pada bidang

\footnotetext{
25 Contoh RUU Perubahan Undang-Undang Nomor 1 Tahun 1974 tentang Perkawinan, RUU Perubahan Undang-Undang Nomor 20 Tahun 2003 tentang Sistem Pendidikan Nasional, keduanya masuk Prolegnas tetapi belum pernah dibahas.

26 Lihat penjelasan Pasal 18, yang dimaksud Ketetapan Majelis Permusyawaratan Rakyat adalah ketetapan yang masih berlaku sebagaimana dimaksud dalam Pasal 2 dan Pasal 4 Ketetapan Majelis Permusyawaratan Rakyat Republik Indonesia Nomor: I/MPR/2003 tentang Peninjauan terhadap Materi dan Status Hukum Ketetapan Majelis Permusyawaratan Rakyat Sementara dan Ketetapan Majelis Permusyawaratan Rakyat Tahun 1960 sampai dengan Tahun 2002, tanggal 7 Agustus 2003.

27 Pasal 12 Peraturan Presiden Nomor 87 Tahun 2014 tentang Peraturan Pelaksanaan Undang-Undang Nomor 12 Tahun 2011 tentang Pembentukan Peraturan Perundang-undangan.

28 Lihat Pasal 10 ayat (1) Undang-Undang Nomor 11 Tahun 2012, materi muatan UU:

a. pengaturan lebih lanjut mengenai ketentuan Undang-Undang Dasar Negara Republik Indonesia Tahun 1945;

b. perintah suatu Undang-Undang untuk diatur dengan Undang-Undang;

c. pengesahan perjanjian internasional tertentu;

d. tindak lanjut atas putusan Mahkamah Konstitusi; dan/atau

e. pemenuhan kebutuhan hukum dalam masyarakat.

29 Pasal 11 ayat (3) Peraturan Presiden No. 87 Tahun 2014 tentang Peraturan Pelaksanaan Undang-Undang Nomor 12 Tahun 2011 tentang Pembentukan Peraturan Perundang-undangan.
} 
legislasi tertentu, tetapi hal ini tidak terbatas karena jika ada usulan RUU di luar bidang tertentu tetap akan dibahas secara tripartit.

Pembahasan secara tripartit ini perlu disepakati sedari awal sehingga tidak menghambat proses berikutnya. Kesepakatan tersebut terkait dengan jumlah RUU yang akan diusulkan dalam 5 tahunan yang mengakomodasi usulan DPR, DPD dan Pemerintah, karena ketiga lembaga ini tidak ada mandat untuk saling mengontrol atau memveto setiap usulan. Dalam konteks ini DPD dapat turut serta mengambil keputusan atas RUU yang diusulkan oleh DPR dan/atau Pemerintah, atau sebaliknya. Untuk memudahkan mekanisme kerja dalam pengambilan keputusan perlu ada kesamaan persepsi sehingga tidak mengedepankan voting tetapi musyawarah dengan melihat parameter usulan RUU dan sekaligus mengukur urgensi kebutuhan masyarakat. UU MD3 baru tidak mengatur interkameral yang memungkinkan adanya checks and balances antara DPR dan DPD dalam proses legislasi. Oleh karena itu nilai kebersamaan dengan berlandaskan musyawarah menjadi model hubungan dalam pembentukan UU yang dimulai dari perencanaan hingga pembahasan.

Konstruksi model Pembahasan RUU secara tripartit menurut pertimbangan MK yang diakomodasi dalam UU MD3 baru sebagai berikut: ${ }^{30}$

a. Pembahasan pada Tingkat I oleh komisi atau panitia khusus DPR, DPD sudah dilibatkan sejak penyampaian pengantar musyawarah, mengajukan, dan membahas Daftar Inventaris Masalah (DIM) serta menyampaikan pendapat mini sebagai tahap akhir dalam pembahasan di Tingkat I. ${ }^{31}$

b. Pembahasan Tingkat II, DPD menyampaikan pendapat dalam rapat paripurna DPR sampai dengan sebelum tahap persetujuan, karena pengambilan persetujuan merupakan kewenangan DPR dan Presiden. c. Pembahasan RUU dari DPD harus diperlakukan sama dengan RUU dari Presiden dan DPR dengan konstruksi: ${ }^{32}$

1) RUU dari Presiden:

Presiden diberikan kesempatan memberikan penjelasan, sedangkan DPR dan DPD memberikan pandangan.

2) RUU dari DPR:

DPR diberikan kesempatan memberikan penjelasan, sedangkan Presiden dan DPD memberikan pandangan.

3) RUU dari DPD:

DPD diberikan kesempatan memberikan penjelasan, sedangkan DPR dan Presiden memberikan pandangan.

d. Konstruksi UUD 1945 mengenai pembahasan RUU antara Presiden dan DPR, serta DPD (dalam hal terkait RUU tertentu) dilakukan antara lembaga negara, sehingga DIM, hanya diajukan oleh masing-masing lembaga negara. Dalam hal ini DIM diajukan oleh DPR, bukan lagi DIM yang diajukan oleh fraksi.

e. Pembahasan DIM pada tingkat Alat Kelengkapan DPR yang sudah mengundang Presiden dan/atau sudah mengundang DPD, maka DPR dalam pembahasan DIM hanya diwakili oleh Alat Kelengkapan DPR sebagai satu kesatuan kelembagaan.

Dengan terlibatnya 3 (tiga) lembaga ini maka proses pembahasan RUU dilakukan dalam forum trilateral meeting. Mekanismenya menjadi panjang karena DIM dapat berasal sekaligus dari 3 (tiga) lembaga, manakala yang diajukan adalah sama-sama RUU terkait dengan kewenangan bidang legislasi tertentu DPD (Pasal 22D UUD 1945). Masing-masing lembaga tidak dapat saling memveto, tetapi putusan akhir hanya ada pada DPR dan Presiden. Keberatan DPD terhadap suatu ketentuan hanya dapat disampaikan dengan pandangan/pendapat mini pada waktu pembahasan

\footnotetext{
Setjen DPD RI, 2013, Fungsi Legislasi Dewan Perwakilan Daerah Pasca Putusan Mahkamah Konstitusi, Setjen DPD RI, Jakarta, hlm. 30.

31 Pasal 169 Undang-Undang Nomor 17 Tahun 2014 tentang Majelis Permusyawaratan Rakyat, Dewan Perwakilan Rakyat, Dewan Perwakilan Daerah, Dan Dewan Perwakilan Rakyat Daerah (Lembaran Negara Republik Indonesia Tahun 2014 Nomor 182, Lembaran Negara Republik Indonesia Nomor 5568).

32 Pasal 170 Undang-Undang Nomor 17 Tahun 2014 tentang Majelis Permusyawaratan Rakyat, Dewan Perwakilan Rakyat, Dewan Perwakilan Daerah, Dan Dewan Perwakilan Rakyat Daerah (Lembaran Negara Republik Indonesia Tahun 2014 Nomor 182, Lembaran Negara Republik Indonesia Nomor 5568).
} 
RUU tingkat II. ${ }^{33}$ Sebaiknya pendapat mini DPD ini menjadi bahan pertimbangan DPR dan Pemerintah dalam pengambilan keputusan di sidang paripurna, sehingga akan dapat mengurangi beban DPR dan Pemerintah terhadap pengujian UU yang dilakukan oleh DPD karena adanya penolakan terhadap pendapat mini DPD.

\section{Kesimpulan}

Selama masih menggunakan hasil revisi UUD 1945, maka DPD sebagai bagian dari parlemen Indonesia tetap mencerminkan sifat soft bicameralism walaupun disebut sebagai lembaga negara tetapi kedudukan tetap tidak setara dengan DPR. Pasca putusan MK tidak menggeser atau mengubah sifat ini karena dalam melaksanakan fungsi legislasi DPD hanya diberi tambahan porsi keterlibatannya, yang semula terlibat tetapi pada pra pembahasan RUU karena posisinya disetarakan oleh UU MD3 dan UU P3 sama seperti alatalat kelengkapan DPR. Dengan adanya Putusan Mahkamah Konstitusi No. 92/PUU-X/2012, DPD terlibat dalam proses legislasi tetapi tidak sampai mengambil porsi persetujuan bersama.

Implikasi putusan MK ini tidak cukup signifikan jika DPD tidak menyetujui suatu RUU yang berkaitan dengan kewenangan DPD pada bidang legislasi tertentu (Pasal 22D ayat (1) UUD 1945). RUU tersebut bisa jadi tetap berjalan dan jadi UU karena wilayah persetujuan ada pada DPR dan Pemerintah. Pendapat mini DPD terkait dengan RUU bidang tertentu yang menjadi kewenangannya tidak mengikat secara hukum bagi DPR dan Pemerintah. Oleh karena itu, perlu dibangun kesepakatan politik interkameral jika DPD tidak setuju atas rumusan tertentu maka ketidaksetujuan ini menjadi bagian yang perlu dipertimbangkan oleh fraksi/anggota DPR pada waktu pengambilan keputusan akhir di sidang paripurna, sehingga suara mandat rakyat langsung lewat DPD tidak dikalahkan oleh agregasi partai di DPR.

Hubungan kelembagaan tripartit dalam proses pembentukan UU Pasca Putusan MK jika dapat dilakukan secara musyawarah sejak proses perencanaan legislasi tidak akan memperpanjang birokrasi legislasi. Terhadap usulan RUU yang sama-sama diajukan oleh DPR, DPD dan Pemerintah diakomodasi dan ditawarkan oleh DPR sesuai dengan kesiapan lembaga berdasarkan parameter yang telah disepakati dengan menitikberatkan pada DPD jika muatannya terkait kewenangan DPD.

\section{DAFTAR PUSTAKA}

A. Buku

Asshiddiqie, Jimly, 2006, Konstitusi dan Konstitusionalisme, Konstitusi Press, Jakarta. 2006 Pengantar Ilmu Hukum Tata

Negara, Sekretariat Jenderal Mahkamah Konstitusi Republik Indonesia, Jakarta. ,2007, Implikasi Perubahan UUD 1945 terhadap Pembangunan Hukum Nasional, Sekretariat Jenderal Mahkamah Konstitusi Republik Indonesia, Jakarta.

Budiardjo, Miriam, 2006, Dasar-Dasar Ilmu Politik, Gramedia Pustaka Utama, Jakarta. Istanto, Sugeng, F., 2007, Penelitian Hukum, Ganda,
Yogyakarta.

Lijphart, Arjend, 1995, Sistem Pemerintahan Parlementer dan Presidensial, Raja Grafindo Persada, Jakarta.

Manan, Bagir, 1995, Pertumbuhan dan Perkembangan Konstitusi Suatu Negara, Mandar Maju, Bandung. , 2004, Teori dan Politik Konstitusi, Fakultas Hukum UII Press, Yogyakarta Mahkamah Konstitusi, 2010, Buku Hukum Acara Mahkamah Konstitusi, Sekretariat Jenderal dan Kepaniteraan Mahkamah Konstitusi dan Asosiasi Pengajar Hukum Acara Mahkamah

33 Penjelasan Pasal 170 ayat (4) huruf b: Pendapat mini DPD hanya disampaikan terhadap rancangan undang-undang yang berkaitan dengan kewenangan DPD. 
Konstitusi, Jakarta.

Marzuki, Peter Mahmud, 2005, Penelitian Hukum, Kencana, Jakarta.

Setjen DPD RI, 2013, Fungsi Legislasi Dewan Perwakilan Daerah Pasca Putusan Mahkamah Konstitusi, Setjen DPD RI, Jakarta.

Subekti Valina, Singka, 2008, Menyusun Konstitusi Transisi: Pergulatan Kepentingan dan Pemikiran dalam Proses Perubahan UUD 1945, Raja Grafindo Persada, Jakarta.

Yani, Ahmad, 2011, Pembentukan Undang-Undang dan Perda, Rajawali Pers, Jakarta.

\section{B. Jurnal}

Aziz, Machmud, "Peran Dewan Perwakilan Daerah dalam Pembentukan Undang Undang", Jurnal Legislasi Indonesia, Vol. 2, No. 3, September 2005.

Marzuki, Laica, "Keberadaan DPD dan Kaitannya dalam Pembentukan Undang Undang", Jurnal Legislasi Indonesia, Vol. 2, No. 3, September 2005.

\section{Hasil Penelitian}

Isra, Saldi, 2009, Pergeseran Fungsi Legislasi dalam Sistem Pemerintahan Indonesia Setelah Perubahan Undang-Undang Dasar 1945, Disertasi, Program Pascasarjana Fakultas Hukum Universitas Gadjah Mada.

\section{Sumber Internet}

Siahaan, Maruarar, "Checks and Balances dan Judicial Review: Legislasi Di Indonesia", http://www.jimlyschool.com/ read/analisis/333/checks-and-balancesdan-judicial-review-dalam-legislasi-diindonesia/, diakses 27 Mei 2014.

\section{E. Makalah}

Susanti, Bivitri, 2007, "Penguatan Kewenangan DPD dan Pasal-Pasal Lain yang Terkait di Bidang Legislasi, Anggaran dan Pengawasan", Makalah, disampaikan dalam Pertemuan ahli Hukum Tata Negara, Universitas 45 Makassar, Makassar, 30 Juni 2007.

\section{F. Putusan Pengadilan}

Putusan Nomor 104/PUU-X/2012 tentang Pengujian Undang-Undang Nom `or 27 Tahun 2009 tentang Majelis Permusyawaratan Rakyat, Dewan Perwakilan Rakyat, Dewan Perwakilan Daerah dan Dewan Perwakilan Rakyat Daerah serta Undang-Undang Nomor 12 Tahun 2011 tentang Pembentukan Peraturan Perundang-undangan.

Putusan Nomor 92/PUU-X/2012 tentang Pengujian Undang-Undang Nomor 27 Tahun 2009 tentang Majelis Permusyawaratan Rakyat, Dewan Perwakilan Rakyat, Dewan Perwakilan Daerah dan Dewan Perwakilan Rakyat Daerah serta Undang-Undang Nomor 12 Tahun 2011 tentang Pembentukan Peraturan Perundang-undangan. 